Vol. 2 No. 3- December 2021

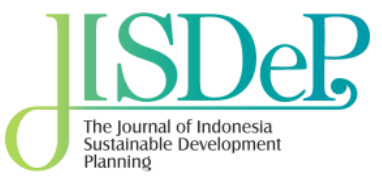

E-ISSN: 2722-0842 | P-ISSN: 2721-8309

Available online at

journal.pusbindiklatren.bappenas.go.id

Kementerian PPN/

Bappenas

Research Paper

\title{
The Effect of General and Vocational High School Quality on Labor Market Outcomes in Indonesia
}

\author{
Rizqi Qurniawan ${ }^{1}$ and Thia Jasmina ${ }^{2}$ \\ Department of Economics, Faculty of Economics and Business, University of Indonesia ${ }^{1}$ \\ Department of Economics, Faculty of Economics and Business, University of Indonesia ${ }^{2}$ \\ Email: 1rizqi.qurniawan@ui.ac.id, ${ }^{2}$ thia.jasmina@ui.ac.id
}

\begin{tabular}{|c|c|c|}
\hline \multicolumn{3}{|c|}{ ABSTRACT } \\
\hline \multicolumn{3}{|c|}{$\begin{array}{l}\text { To improve the quality and competitiveness of human capital and correspond to the Sustainable } \\
\text { velopment Goals (SDGs) } 4 \text { especially target } 4.3 \text {, to ensure equal access for all women and men to affordable } \\
\text { d quality technical, vocational and tertiary education, Indonesia has been focusing on improving the quality } \\
\text { secondary education. However, empirical data and previous research showed that secondary school } \\
\text { aduates in Indonesia face high unemployment and income differences, especially vocational school } \\
\text { aduates. The quality of secondary high schools plays an important role in determining the years of schooling } \\
\text { the graduates and indirectly impacts labor market outcomes. Using longitudinal panel data at the individual } \\
\text { el from the Indonesia Family Life Survey (IFLS) of } 2000,2007 \text {, and } 2014 \text {; and applying education production } \\
\text { nction and Mincer earning equation, this study finds that the difference in wages between graduates of } \\
\text { neral and vocational high schools is not statistically significant despite the school quality. However, } \\
\text { alyzing within the vocational high schools shows that better quality of vocational high schools increases } \\
\text { ars of schooling of its graduates as they can access tertiary education, and subsequently increases their } \\
\text { rformance in the labor market. This finding indicates that policies to improve school quality, especially } \\
\text { cational high schools, should be enhanced. }\end{array}$} \\
\hline & & chools, education production function, \\
\hline $\begin{array}{l}\text { ARTICLE INFO } \\
\text { Received: September 25, } 2021 \\
\text { Received in revised form: November 21, } \\
2021 \\
\text { Accepted: December 29, } 2021\end{array}$ & $\begin{array}{l}\text { JISDeP - The Journal of Indonesia } \\
\text { Sustainable Development Planning } \\
\text { Published by Centre for Planners' } \\
\text { Development, Education, and Training } \\
\text { (Pusbindiklatren), } \\
\text { Ministry of National Development } \\
\text { Planning/ National Development } \\
\text { Planning Agency (Bappenas), Republic } \\
\text { of Indonesia }\end{array}$ & $\begin{array}{l}\text { Address: Jalan Proklamasi 70, } \\
\text { Central Jakarta, Indonesia 10320 } \\
\text { Phone: }+622131928280 / 31928285 \\
\text { Fax: }+622131928281 \\
\text { E-mail: journal.pusbindiklatren@bappenas.go.id }\end{array}$ \\
\hline
\end{tabular}




\section{Introduction}

The 4th Sustainable Development Goals (SDGs) focus on inclusive and quality education for all and reaffirm that education is a means to enhance the quality of human capital and increase economic growth. One of the targets in SDG 4 is to ensure equal access for all women and men to affordable and quality technical, vocational and tertiary education, including university, as in SDG 4 target 4.3 (Badan Perencanaan Pembangunan Nasional [Bappenas], 2021; Ministry of Education and Culture, 2017). Secondary education, both vocational and general education, is a prominent level of education in increasing human capital as the graduates of this level of education can either be working or entering tertiary education. Indonesia is committed to improving the quality and competitiveness of human capital, which is in line with the commitment to achieving SDG 4. One main strategic program to enhance human capital is with the improvement of technical and vocational and training (TVET) as stated in Presidential Regulation No. 18 of 2020 concerning the Medium-Term Development Plan of 2020-2024 (2020).

A number of cross-country studies showed supporting and disputing arguments on vocational high schools (SMK) in comparison to general high schools (SMA). For the case of Indonesia, studies such as by Newhouse and Suryadarma (2011), and Mahirda and Wahyuni (2016), showed that the education return of SMK graduates in the labor market is relatively lower compared to SMA's graduates. The portfolio of TVET in Indonesia comprises both formal and non-formal education. Formal education consists of vocational secondary and tertiary education, whereas non-formal education consists of vocational training centers. Formal secondary education consists of general and vocational high schools as a sub-system in Indonesia's national education system. In SMA, students are more focused on studying academic skills to continue to tertiary education. In contrast, in SMK, students learn more practical skills so that after graduating, they will be ready to work in industry, independent businesses, or other employment fields.

The number of secondary schools increased significantly from 2012 to 2019 by $19.9 \%$ and $13.8 \%$ for SMK and SMA, respectively (Jasmina, 2020). According to the government's policy stated in 2006, to increase the number of SMK (Newhouse and Suryadarma, 2011), the number of vocational high schools and their students has increased. To enhance the quality of SMK in Indonesia, the government issued Presidential Instruction Number 9 of 2016 concerning the revitalization of vocational high schools. However, the results of the instruction are not yet apparent. For the last five years, the unemployment rate in Indonesia has been dominated by workers who graduated from secondary education, reaching $11.29 \%$ in 2020 . Specifically, from 2018 to 2020, a high proportion of unemployed workers are vocational high school graduates (Figure 1).

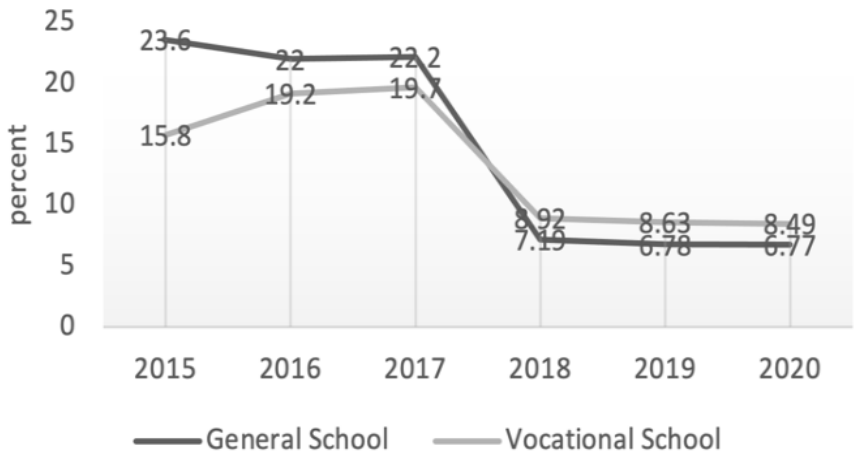

Figure 1. Unemployment Rate of Indonesia by Education, 2015-2020

Central Statistics Agency (2021a), edited 
Moreover, Figure 2 shows that since 2016 the general high school graduates have higher average hourly wages than vocational graduates, but the difference is not significant. Despite extensive research into the subject, the debate regarding the returns of education between vocational and general high schools is not conclusive in Indonesia. Newhouse and Suryadarma (2011) found that males with general high school educations earned higher wages (premium wages) than individuals who attended vocational schools. In contrast, Mahirda and Wahyuni (2016) did not find a significant difference between the salaries of individuals who graduated from SMA and SMK.

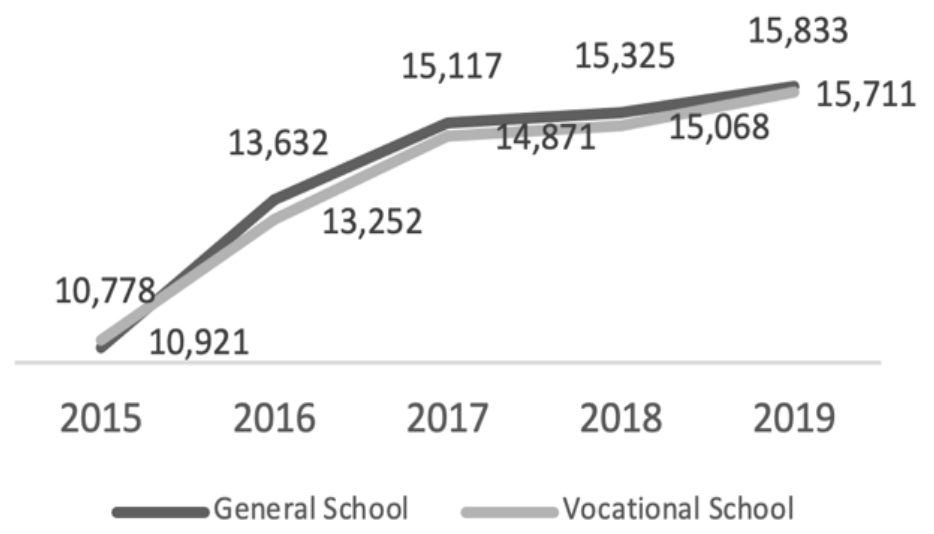

Figure 2. Average Hourly Wages of Workers in Rupiah Central Statistics Agency (2021b), edited

Nevertheless, Quarina and Pasay (2007) and a recent study by Bhismananda (2020) found that attending vocational schools provides higher salaries/wages and higher employment rates than general high school graduates receive. The previous literature also reveals that years of education are a proxy for return to education as the labor market outcome. However, no literature in the context of Indonesia has discussed the role of school quality in graduates achieving high wages or salaries in the future. As Newhouse and Suryadarma (2011) explained, the wage-premium differences between graduates of general high schools and vocational high schools can be due to differences in quality between general high schools and vocational schools. By looking at educational returns, the school quality must be considered one factor that might affect the graduates' educational outcomes in the labor market (Card and Krueger, 1992; Behrman and Birdsall, 1983; Guo, 2018).

Currently, SMK in Indonesia still has problems in terms of quality. The schools have limited teachers, especially vocational teachers, who teach groups of vocational subjects. In 2015 only $22.3 \%$ of vocational teachers taught according to their field of competence (Ministry of Education and Culture, 2017). In addition, the recent data from the Ministry of Education and Culture (2016a) showed that public vocational schools experience a shortage of vocational teachers of 41,861 , while private vocational schools lack 50,000 teachers (Ministry of Education and Culture, 2016b). SMK has limited vocational teachers even though SMK students are increasing every year. As result in Figure 3, the student-to-teacher ratio in vocational schools is higher than that in general high schools, and this seems to impact the learning competencies of vocational students. 


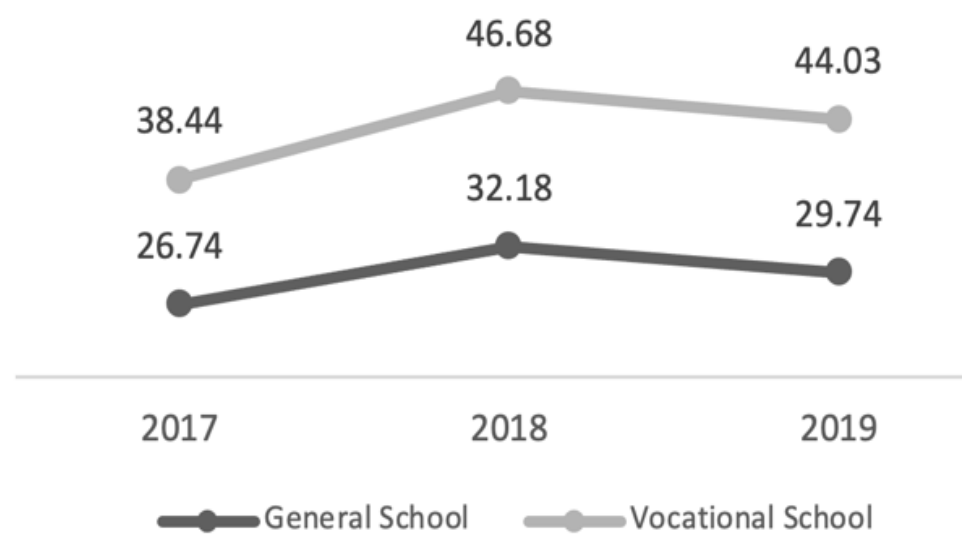

Figure 3. The ratio of Students to Public Teachers in 2017-2019 Ministry of Education and Culture, 2020

To improve the quality of human capital and achieve the quality of education, especially at general and vocational secondary as targeted in SGD 4.3, analyzing how the quality of respective schools affects education output and, hence, affects labor market income is important. Therefore, this study aims to determine how general and vocational high school quality affects labor market income or return to education by applying longitudinal data from the Indonesia Family Live Surveys (IFLS) of 2000, 2007, and 2014.

This study does not specifically discuss achieving SDG 4. However, this study argues that understanding the relationship between the quality of vocational and general high schools and the years of schooling; subsequently understanding the relationship between the years of schooling and labor market income, can contribute to policy recommendation to improve quality of education and enhance human capital, which is in line to SDG 4, specifically target 4.3. Better quality of SMA/SMK will indirectly lead the graduates to continue their education, and hence they are expected to earn higher incomes.

The study applies a two-step regression: (i) the theory of education production function of Hanushek (1979) with years of schooling as an output of education that might be affected by educational input factors such as school quality, individual performance, and family background; and (ii) the Mincer (1974) equation model with labor market income as a return on education that might be affected by years of schooling. Following previous studies, the school quality in this study is defined as the availability of school input factors with regards to the number of students, such as teachers, school facilities, and school expenditure (Card and Krueger, 1992; Case and Yogo, 1999; Dearden et al., 2002; Bedi and Edwards, 2002; Guo, 2018).

\section{Literature Review}

\section{Supply and Demand of Education}

Education from an economic perspective can be reviewed from the supply-side and the demandside. Firstly, from the supply side, education is discussed from the point of view of educational producers such as educational institutions and other factors such as innate factors and family conditions. As pointed out by Hanushek (1979), the output of the educational process, namely student achievement such as academic grades, is influenced by inputs that are directly controlled by policymakers (characteristics of schools, teachers, and curriculum) and is also influenced by student academic performance factors, family background, and peer conditions. Educational outputs, apart from being shown in student test scores, can also be seen in 
educational attainments, such as gross and net participation rates, or shown by the number of years of schooling attended by students (Garniss, 2006). However, the problem with the general measure of years of schooling is that it simply calculates time spent in school without assessing what is happening at school, so it does not provide a complete or accurate picture of the effect of school outcomes on income (Hanushek, 1979). The return on education assumes that one year of schooling results in the same number of achievements over time. Finally, this school outcome measure ignores the extensive policy debate about ways to improve school quality. Whereas school quality also influences the learning process and determines the academic performance of students while at school.

Secondly, from the demand side, education is considered a service that students consume. According to the human capital theory, education focuses on maximizing their expected lifetime earnings (Becker, 1975). The economic benefits that a person expects from investing in education in the form of salaries, wages, profits earned at work and are called educational returns. The measurement of the labor returns made by Mincer (1974) shows that employment earnings are a function of schooling and labor market experience. The Mincer equation estimates the average monetary returns of one additional year of education.

\section{Previous Empirical Studies}

Some previous studies that explained the supply-side impact of education discussed the quantity and quality of schools on educational output. Duflo (2001) focused more on the quantity of schools regarding the impact of the construction of primary education schools in Indonesia from 1974 to 1979. As a result, the construction of 61,000 primary schools during that period significantly increased the student enrollment rate from $69 \%$ to $83 \%$ and increased future income by $2.7 \%$ because of the increase in years of schooling. In addition, various literature also reveals that there is a relationship between school quality and wages. Studies such as Card and Krueger (1992) in the United States and Case and Yogo (1999) in South Africa showed a significant negative impact of school quality, indicated by the student-to-teacher ratio, on individuals' income. However, other studies such as Dearden et al. (2002) found that school quality was not a significant factor in determining income when family educational background and individual abilities were included as control variables.

Despite using on the student-to-teacher ratio to measure school quality, other studies have examined other factors such as the availability of school facilities and the average school expenditure per student. Bedi and Edwards (2002) used the percentage of teachers who graduated with bachelor's degrees, the length of time the teacher had studied, the percentage of schools with water and electricity facilities, and the student-to-class ratio as variables in measuring school quality. A recent study, Guo (2018), uses proxies of school expenditure per student and student-teacher ratio to reflect school quality. With significant results, school spending per student is positively correlated with individual income and indirectly affects educational outcomes.

The previous studies explain the influence of school quality only at the basic education level, namely elementary or junior high school. However, studies examining the effect of school quality on secondary education are limited. Strayer (2002) studied the effect of the quality of high school education on the income of individuals who choose to continue to college compared to those who do not attend college. Strayer (2002) first estimated the role of school quality on individual preferences for continuing tertiary education and incorporated these factors into the Mincer earning equation. The study found that the quality of secondary education schools, as measured by the student-to-teacher ratio and the percentage of teachers who graduated with a bachelor's degree, significantly affected students' chances of pursuing higher education and attending colleges and consistently increased their wages compared to individuals who did not attend 
colleges. The schools' quality affects the length of education of individuals, which later will affect their respective wages.

Studies on the impact of secondary school quality in vocational or general schools are still limited, especially in Indonesia. Previous studies such as Newhouse and Suryadarma (2011), Bhismananda (2020), Quarina and Pasay (2007), and Mahirda and Wahyuni (2016) estimated education outcomes regardless of the characteristics of the schools. In Indonesia, individuals who graduate from general high school are intended to continue tertiary education after graduation. In contrast, vocational school graduates can choose to leave school because vocational education aims to produce graduates who can immediately enter the labor market. Results from those studies implied that society and companies have a better perception of workers who graduate from general high school than those who graduate from vocational high school.

Higher returns on education for general high school graduates than for vocational school graduates were reported by Newhouse and Suryadarma (2011). The study used IFLS panel data from 1993 to 2000 and calculated students' probabilities of attending school in four categories of secondary school: SMA and SMK for each school status, private or public. The result of this study is in contrast to Quarina and Pasay (2007), Mahirda and Wahyuni (2016), and Bhismananda (2020), all of which used the latest IFLS data, 2014/2007. Bhismananda (2020) and Quarina and Pasay (2007) found a high rate of return on individual education for individuals who graduate from vocational education than individuals who graduate from general high school. However, Mahirda and Wahyuni (2016) did not find any difference in educational outcomes between high school and vocational high school graduates. Moreover, Quarina and Pasay (2007), Mahirda and Wahyuni (2016), and Bhismananda (2020) have not been able to explain the educational track of individuals after graduating from high school to continuing their studies at the tertiary level and have not explained the effect of school quality which could be the cause of the difference in wages between the two groups of graduates.

\section{Methodology}

\section{Research Framework}

This study applies the econometrics method to estimate the relationship between the quality of SMK/SMA and years of schooling and further estimates the relationship between the years of schooling to future wages/income. This study first analyzes the effect of education inputs on education output and outcome. First, we explore the effect of educational inputs, such as school quality, on years of schooling following the educational production function theory by Hanushek (1979). The years of schooling as educational output is influenced by inputs, such as individual abilities, family background, and school quality factors. The relationship of input, output, and outcome of education is presented in Figure 4. The educational input factor, especially the quality of schools, is also distinguished based on the types of schools attended, SMA or SMK, considering that the individual and school characteristics are different in the respective schools. In contrast to previous studies, the individual preference factors for choosing the types of secondary schools (SMA/SMK) and tertiary institution are assumed to be constant. The conceptual framework of this study is shown in Figure 5.

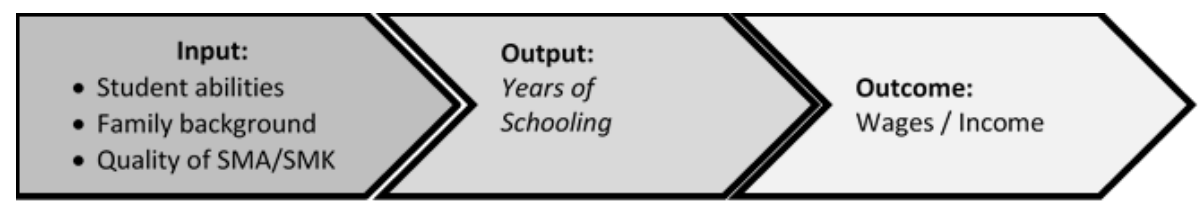

Figure 4. Relationship of School Quality Factors to Educational Output and Labor Outcomes 
The adjustment in the years of schooling has affected wages as a return on education, according to Mincer (1974). Since we documented the educational track of individuals graduating from SMA/SMK, the current wage (2014) is indirectly influenced by educational input factors when the individual attended school in 2000, 2007, and 2014. In addition, school quality factors and other educational inputs are assumed not to directly influence income or salary (Card, 2001). However, as a research limitation, this study does not discuss school quality factors that may correlate with individual quality as measured by student test scores and assume that education is an investment.

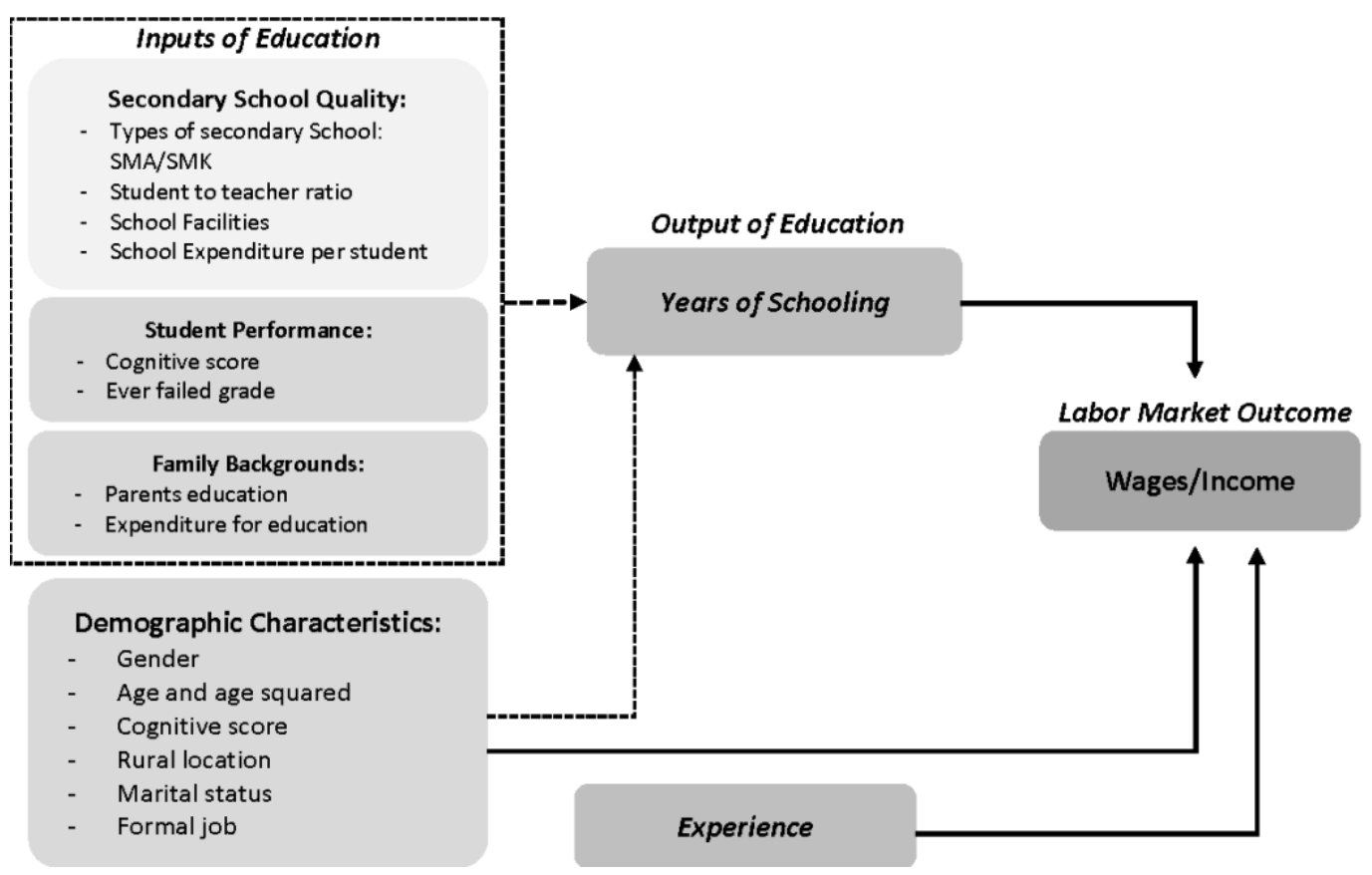

Figure 5. Conceptual Framework of the Study

\section{Data and Sample}

The empirical analysis draws on datasets from the Indonesian Family Life Survey (IFLS), a longitudinal household survey conducted by the Research and Development (RAND) Corporation. Three full follow-up waves were conducted in 2000, 2007, and 2014, and each wave contains two data sets (Strauss et al., 2004; Strauss et al., 2009; Strauss et al., 2016). The first dataset represents individual characteristics such as demographic characteristics, educational background as type and status of the school, academic performance, educational assistance, employment, and health characteristics. Second, the community dataset represents an educational facility book that explains school characteristics, such as school facilities and descriptions (status and types of schools, number of teachers and students), and characteristics of each school member, including the principal, teachers, and students.

This study used three waves of IFLS, combining both individual and community datasets. The individual dataset is categorized according to working population age and attendance at general high schools or vocational schools in 2000, 2007, and 2014 to capture demographic information, individual performance, and the family's educational and economic background when the individual attended school in the survey year. Subsequently, to capture the school quality, the data were merged with the community dataset in each survey year based on the location of the individuals when they attended 
secondary schools. The data was then aggregated to the district or city level while considering the weight of facilities from each community. It is acknowledged that there might be a potential bias and overestimates of the aggregated data due to the heterogeneity of school characteristics within each region.

As a result, the characteristics of the first sample are those who have attended general high school or vocational school (currently in school and graduated in 2000, 2007, and 2014) and entered the workforce in 2014, as shown in Table 1.

Table 1 Number Samples

\begin{tabular}{c|ccc}
\hline Characteristics: & SMK & SMA & Total \\
\hline First step: ever schooled SMA/SMK & 1142 & 1906 & $\mathbf{3 0 4 8}$ \\
\hline Second step: having income and worked & 585 & 969 & $\mathbf{1 5 5 4}$ \\
\hline
\end{tabular}

Source: IFLS 3, 4, and 5 (author calculation)

Table 2 shows a descriptive statistic of the sample for general high schools (SMA) and vocational high schools (SMK) across districts or cities in Indonesia. Comparing the indicators that reflect school quality in this study, the data show that, on average, SMA is of higher quality than SMK across districtscities in Indonesia.

Table 2 Descriptive Summary Statistics of School Quality between General and Vocational High School

\begin{tabular}{|c|c|c|c|c|c|}
\hline Variable & Obs & Mean & Std. Dev. & Min & Max \\
\hline \multicolumn{6}{|c|}{ General High School (SMA) graduates } \\
\hline Student to teacher ratio & 163 & 13.218 & 3.128 & 5.69 & 23.39 \\
\hline Number of school facilities & 163 & 9.671 & 3.04 & 1 & 17 \\
\hline School expenditure per student* & 163 & $128,825.25$ & $1,076,810.8$ & 14.939 & $13,435,793$ \\
\hline Cognitive score & 1906 & 52.08 & 27.12 & 0 & 100 \\
\hline Father years of schooling & 1906 & 10.16 & 4.22 & 0 & 22 \\
\hline Mother years of schooling & 1906 & 9.32 & 4.33 & 0 & 18 \\
\hline Education expenditure & 1906 & 680.53 & 796.93 & 1.77 & 10138.02 \\
\hline \multicolumn{6}{|c|}{ Vocational High School (SMK) graduates } \\
\hline Student to teacher ratio & 125 & 14.841 & 5.593 & 3.845 & 38.805 \\
\hline Number of school facilities & 125 & 8.341 & 3.265 & 1 & 14.924 \\
\hline School expenditure per student* & 125 & $54,186.614$ & $231,306.79$ & 11.736 & $2,169,968$ \\
\hline Cognitive score & 1142 & 51.09 & 25.17 & 0 & 100 \\
\hline Father years of schooling & 1142 & 8.94 & 4.03 & 0 & 18 \\
\hline Mother years of schooling & 1142 & 8.02 & 4.09 & 0 & 18 \\
\hline Education expenditure & 1142 & 557.08 & 657.89 & 3.65 & 10138.02 \\
\hline
\end{tabular}

Souces: IFLS 3, 4, and 5 (author's calculation)

First, general schools had a student-teacher ratio of 13 , which is lower than vocational schools at 15 , which indicates that vocational teachers teach more students. In addition, the standard deviation of the student-to-teacher ratio for vocational schools is higher than in general schools, which indicates that SMK teachers are not evenly distributed compared to SMA. Second, SMA schools have more physical facilities than SMK schools. Third, the average school expenditures per student for SMK are lower than SMA. The facilities and school funds for vocational schools should be more supportive and include laboratories, internet access, and practice facilities that can improve the skills of vocational students (Organisation for Economic Co-operation and Development [OECD], 2020a; OECD, 2020b).

Since this study observed the effect of educational inputs on years of student attendance in school, we also compared educational tracks for vocational and general graduates to the average salary earned. Table 3 shows that most individuals in the sample continued their studies until they graduated from 
SMA/SMK. However, general school graduates continue to college more often than vocational school graduates. The average wage for general high school graduates is Rp1,503,507, higher than the average wage for vocational high school graduates. Meanwhile, if it is dissected at each educational level, the average wages of SMA and SMK graduates are not significantly different. Moreover, SMK graduates who continued their education to a diploma had a higher wage than those who had not finished or graduated from SMK. In other words, SMK graduates are better off continuing to higher education to get better compensation.

Table 3. Monthly Average Wages based on Educational Track

\begin{tabular}{|c|c|c|c|c|}
\hline \multirow{2}{*}{ Education Track/Level } & \multicolumn{2}{|c|}{ General High School Graduates } & \multicolumn{2}{|c|}{ Vocational High School Graduates } \\
\hline & $\mathbf{N}$ & Mean (Rp) & Mean (Rp) & $\mathbf{N}$ \\
\hline Have not finished high school & 54 & $1,006,509.6$ & $454,619.21$ & 52 \\
\hline High school graduates & 552 & $1,435,608.3$ & $1,404,305.3$ & 446 \\
\hline Diploma I-III or still attend college & 142 & $1,713,470.4$ & $1,860,146.3$ & 57 \\
\hline Bachelor degree or Diploma IV & 213 & $1,642,439.6$ & $1,787,045.2$ & 30 \\
\hline Master degree or above & 8 & $2,117,344.1$ & - & - \\
\hline Total/Average & 969 & $1,503,507.2$ & $1,383,931.7$ & 585 \\
\hline Minimum & & 41,666 & 35,000 & \\
\hline Maximum & & $5,300,000$ & $4,200,000$ & \\
\hline
\end{tabular}

\section{Methods and Estimation Models}

The quality of SMA/SMK is measured using several indicators based on previous studies and the availably of data in IFLS. First, the effectiveness of the learning process in the classroom is characterized by the student-to-teacher ratio. The higher student-to-teacher ratio means that the teachers must teach many students, which leads to lower learning effectiveness. However, a too low ratio also makes learning activities inefficient because one teacher only teaches a few students. Secondly, aspects of school facilities such as ownership of libraries, fields, canteens, halls, laboratories, internet connections, and other physical facilities also affect outcomes. Third, the financial aspect of schools as measured by school expenditures per student as a resource directly supports the effectiveness and efficiency of education management. Of course, a good quality school will have adequate school facilities and higher school expenditure to support learning activities.

Based on Figure 4, this study looks at the years of schooling as a proxy for return on education. Return on education is also influenced by individual performance and other factors such as family background and school quality, following the theory of the production function of education. Case and Yogo (1999) and Card (1999) reported the educational returns without considering education input factors. Their estimates might be too high and biased because they do not consider individual conditions and school characteristics. Therefore, the best inferential estimation method is a cross-sectional twostep linear regression. The first regression follows the education production function by Hanushek (1979) and proceeds to the second step following the income equation of Mincer (1974). In this context, the two-step regression method can explain the indirect effect of educational inputs, one of which is the quality of SMA/SMK, on the level of wages of individuals as it depends on the years of schooling. In addition, this study uses a second-step regression modified from the previous research by Guo (2018), Bedi and Edwards (2002), and Card and Krueger (2001). They estimate the coefficient of return on education for each district or province cohort. Next, each district's return on education value is used as the dependent variable, influenced by the school quality factor in the second stage of the regression. Guo (2018), Hanushek et al. (1996), and Johnson and Stafford (1973) explained that using two-stage regression and aggregating the educational outcomes and school quality factors at a certain regional level might cause potential bias. They also argued that two-stage regression is not controlled for family 
background and individual performance variables and is insufficient to explain the heterogeneity of individuals in the intra-region.

Each regression is divided into two groups, full sample and separate samples, based on individuals with their respective types of high school, SMA, and SMK. The SMA and SMK graduates are separate samples because their objectives and learning competencies are different even though they are in the same line of secondary education. In addition, the separate samples can show the effect of schools with better quality compared to low-quality schools for each type of school. Meanwhile, the full sample represents the effect of educational inputs of SMK graduates compared to SMA graduates.

\section{First step regression model:}

$$
\begin{aligned}
& \text { Years of schooling }_{\text {isk }} \\
& \qquad \beta_{0}+\beta_{j} \sum_{j=1}^{a} \text { School Quality }_{j i s k t}+\beta_{j} \sum_{j=1}^{a} \text { School Quality }_{j i s k t} \text { \#TypeSchool }_{i} \\
& \\
& +\beta_{j} \sum_{j=1}^{b} \text { Ability }_{j i s t}+\beta_{j} \sum_{j=1}^{c} \text { FamilyBackground }_{j i s t}+\beta_{j} \sum_{j=1}^{a} X_{j i s} \\
& +u_{i s}
\end{aligned}
$$

where:

- Years of schooling = current years of schooling attended by individual $i$ who attended school $s$.

- School quality = school quality vector variables (student-to-teacher ratio, school facilities, school expenses) of individual $i$ who attended school $s$ in district/city $k$ in year of $t$.

- $\quad$ Type school = type of secondary education attended by the individual, 1 for SMK and 0 for SMA (for full sample only).

- $\quad$ Ability $=$ a vector of individual performance, which consists of: cognitive score and whether the individual had failed in school during elementary (SD), junior (SMP), and senior high school (SMA/SMK) for individual $i$ who attended school $s$ in year $t$.

- FamilyBackground = a vector of expenditure for education and educational family background variables for individual $i$ who attended school $s$ in year $t$.

- $X=$ Mincer's control variables, i.e., cognitive score, gender, age, marital status, rural location, employment status of individual $i$ who attended school $s$ in 2014.

Subscript $t$ is the year an individual attended school, in 2014, 2007, and 2000 and subscript $s$ is sample collection by the types of high education attended, SMA, SMK, or secondary education (SMA/SMK).

Before the second stage regression, the study confirms that the error factor Mincer earnings equation must meet the assumption $E(\varepsilon)=0$, meaning that the individual wage should be random. However, from the final sample in Table 1, several individuals from the first stage sample were employed but did not receive wages or did not participate in the labor force because they were in school or unemployed. This condition creates specification bias due to the selection of work participation samples or truncated samples (Heckman, 1979). Therefore, we also determine whether the observation does not result in a specification error by using the two-stage Heckman test before the second-stage regression. This two-stage Heckman test estimates the probability of working participation using the Probit model, in which a correction of sample selectivity or Inverse Mills Ratio (lambda or $\lambda$ ) is obtained. As mentioned in Case and Yogo (1999), the probability of work participation is influenced by the years of schooling, school quality variables, and control variables such as gender, age, and location. The Inverse Mills ratio variable is used as a control variable in the 
two-step linear regression or in the Mincer equation (2) to avoid the problem of specification bias (Heckman, 1979).

After the first regression, we get the predicted number of years of schooling for each observation of general high school and vocational high school graduates from equation (1). Predicted years of schooling is used as an independent variable accompanied by years of experience and other control variables, such as lambda and demographic variables, in equation (2), which is Mincer (1974) income equation.

\section{Second step regression model:}

$$
\begin{aligned}
{\text { In ln } \text { Wage }_{i s}=} & \beta_{0}+\beta_{1 a} \text { Predicted Years of Schooling }_{i s}+\beta_{1 b} \text { Predicted Years of Schooling }_{i s} \# \text { TypeSchool }_{\text {is }} \\
& +\beta_{2} \text { Experience }_{i s}+\beta_{3} \text { Experience }_{i s}^{2}+\beta_{4} \lambda_{i s}+\beta_{j} \sum_{j=1}^{a} X_{j i s} \\
& +\varepsilon_{i s}
\end{aligned}
$$

where:

- $\quad$ ln ln Wage ${ }_{i s}=$ current income/wages of individuals $i$ who had attended school s.

- $\quad$ Predicted Years of schooling is $=$ the estimated value of years of schooling from first step regression in each individual $i$ who had attended school $s$.

- $\quad$ Type school = type of secondary education attended by the individual, 1 for SMK and 0 for SMA (for full sample only).

- $\quad$ Experience $_{i s}=$ current years of work experience followed by individual $i$ who had attended school $s$ in 2014

- $X_{j i s}$ : Mincer's control variables, i.e., cognitive score, gender, age, age squared, marital status, rural location, and employment status of individual $i$ who attends school $s$ in 2014.

In equation (2), $\beta_{1 a}$ is the return for secondary education, representing the percentage of wages in 2014 obtained by SMA or SMK individuals who had attended school in the survey year. The education input factors have corrected the return on education, meaning that better high school quality and more support from other educational inputs can add years of education and indirectly increase individual wages in the future. The variable $\beta_{1 b}$ is the interaction variable between predicted years of schooling and type of schools and shows the percentage of wages obtained by vocational school graduates compared to general high school graduates for given education inputs.

\section{Results and Discussion}

To estimate the relationship between school quality and years of schooling, regression of equation (1) is applied, and the results are shown in Table 4. In column 1 of the table, the variables for the quality of schools: student-to-teacher ratio, school expenditures per student, and school facilities, have a significant influence on the years of schooling. In line with Strayer (2002) findings, higher-quality high schools, characterized by lower student-to-teacher ratios, can increase students' chances of studying for two or four years at college because school learning activities are more effective than those provided to students who attend lower-quality schools. 
Table 4 First Stage Regression: The Effects of School Quality on Years of Completed Schooling

\begin{tabular}{|c|c|c|c|c|c|c|}
\hline \multirow{3}{*}{ VARIABLES } & \multirow{2}{*}{\multicolumn{2}{|c|}{$\frac{\text { (1) }}{\text { Full Sample }}$}} & \multicolumn{2}{|c|}{ (2) } & \multicolumn{2}{|c|}{ (3) } \\
\hline & & & \multicolumn{2}{|c|}{ General School } & \multicolumn{2}{|c|}{ Vocational School } \\
\hline & Coef. & SE & Coef. & SE & Coef. & SE \\
\hline \multicolumn{7}{|l|}{ School Quality } \\
\hline student to teacher ratio & $-0.037 * * *$ & 0.008 & $-0.035 * * *$ & 0.010 & $-0.012^{* *}$ & 0.006 \\
\hline school expenditure (log) & $0.102 * * *$ & 0.014 & $0.111 * * *$ & 0.020 & $0.062 * * *$ & 0.017 \\
\hline school facility & $0.063 * * *$ & 0.011 & $0.046 * * *$ & 0.013 & $0.037 * *$ & 0.016 \\
\hline \multicolumn{7}{|l|}{ School Quality\#Vocational School } \\
\hline student to teacher ratio\#SMK & $0.031 * * *$ & 0.010 & & & & \\
\hline school expenditure\#SMK & $-0.027 * * *$ & 0.008 & & & & \\
\hline school facility\#SMK & $-0.056 * * *$ & 0.008 & & & & \\
\hline \multicolumn{7}{|l|}{ Student Performance } \\
\hline cognitive score & $0.011 * * *$ & 0.001 & $0.012 * * *$ & 0.002 & $0.009 * * *$ & 0.002 \\
\hline Fail grade SD, SMP, SMA & $-0.406 * * *$ & 0.062 & $-0.623 * * *$ & 0.089 & -0.111 & 0.077 \\
\hline \multicolumn{7}{|l|}{ Family Background } \\
\hline Fatheryos & $0.055^{* * *}$ & 0.008 & $0.065^{* * *}$ & 0.011 & $0.036 * * *$ & 0.009 \\
\hline Motheryos & $0.031 * * *$ & 0.008 & $0.041 * * *$ & 0.011 & 0.009 & 0.010 \\
\hline educexp (log) & $0.225^{* * *}$ & 0.028 & $0.278^{* * *}$ & 0.038 & $0.099 * * *$ & 0.036 \\
\hline \multicolumn{7}{|l|}{ Control Variable } \\
\hline Gender & $-0.298 * * *$ & 0.051 & $-0.312 * * *$ & 0.071 & $-0.240 * * *$ & 0.067 \\
\hline Age & $0.446 * * *$ & 0.068 & $0.554 * * *$ & 0.085 & $0.286 * * *$ & 0.097 \\
\hline Agesqr & $-0.006 * * *$ & 0.001 & $-0.007 * * *$ & 0.002 & $-0.003^{*}$ & 0.002 \\
\hline Married & $-0.655^{* * *}$ & 0.076 & $-0.777 * * *$ & 0.104 & $-0.385 * * *$ & 0.097 \\
\hline Rural & $0.194 * * *$ & 0.057 & $0.205^{* * *}$ & 0.075 & $0.155^{* *}$ & 0.079 \\
\hline Formal & $0.389 * * *$ & 0.059 & $0.432 * * *$ & 0.082 & $0.312^{* * *}$ & 0.075 \\
\hline Constant & -0.239 & 0.899 & $-2.728^{* *}$ & 1.168 & $4.195 * * *$ & 1.218 \\
\hline Observations & 3,048 & & 1,906 & & 1,142 & \\
\hline Fstat & 119.29 & & 86.13 & & 44.53 & \\
\hline Prob $>$ F & 0.000 & & 0.000 & & 0.000 & \\
\hline R-squared & 0.401 & & 0.389 & & 0.356 & \\
\hline Adj R-squared & 0.398 & & 0.385 & & 0.348 & \\
\hline
\end{tabular}

However, the interaction variables of school quality and the type of high school (School Facility\#Vocational Schools) show an opposite sign to school quality variables. SMK graduates from highquality schools have lower years of schooling compared to SMA graduates with the same quality. For example, if the student-to-teacher ratio is reduced by one student, it reduces the time needed for SMK graduates to continue their education by 0.031 years compared to SMA graduates with similar school quality in the same district or city. Likewise, each additional one unit of school facility or an increase of $1 \%$ in school expenditure per student reduces years of schooling of SMK graduates compared to individuals graduating from SMA by 0.056 and 0.027 years, respectively. SMA graduates are expected to continue tertiary education, whereas SMK graduates can choose to work after graduation. This finding aligns with Chen (2009) that vocational school graduates in Indonesia are less likely to continue higher education than general high school graduates. However, Chen (2009) also found no significant difference in the probability of work between SMK and SMA graduates.

Table 4, column 2 compares the effects of general high school quality among districts or cities on years of schooling. The quality of SMA has a significant role in supporting graduates to continue their higher education. SMA graduates who attend high-quality schools in the districts or cities (schools with low studentto-teacher ratios, adequate school facilities, and high school expenditure per capita) have longer years of schooling. The results are similar if we compare the effects of vocational high school quality to years of 
schooling among districts or cities, as presented in column 3 of Table 4. Students in high-quality SMK have higher years of schooling as they choose to continue their higher education after graduates.

The positive effect of high school quality is also supported by other educational input factors, such as individual cognitive ability, academic performance, and educational and financial family background. The high cognitive ability for SMK and SMA graduates increases years of schooling by $0.009-0.012$ years. In addition, as indicated by having failed grades, academic performance in schools is significantly positive only in general high school graduates. In addition, general high school graduates have longer years of schooling, which means that they tend to continue their education, as the education level of both father and mother are higher. In contrast, vocational school graduates are driven by their father's education. The education expenses incurred by households are also significant in increasing the years of schooling.

The last discussion in this paper is the second regression according to equation (2), as shown in Table 5 , which follows Mincer's income equation. The year of schooling variable is adjusting the predicted years of schooling from the first regression. In column 1 of Table 5, the return on education for senior high school graduates (SMA and SMK) is 0.259 , which is significant at the $1 \%$ level. It means that an additional one year of schooling increases future wages by $25.9 \%$. The results from the first regression show that the increase of high schools' quality will increase years of schooling; hence indirectly, the increase of school quality will increase future wages. However, the interaction variable of the predicted years of schooling and the type of education shows no significant effect on future wages. Differences in educational inputs between SMA and SMK, one of which is the quality of schools in certain districts or cities, have not been proven to affect differences in income between SMK graduates and SMA graduates. This finding supports Mahirda and Wahyuni (2016) and Chen (2009) empirical results that there is no difference in wages between the two graduates.

Table 5 Second Stage Regression: Estimating the Impact of School Quality on Returns to Education after Selectivity Bias Corrected

\begin{tabular}{|c|c|c|c|c|c|c|}
\hline \multirow{3}{*}{ VARIABLES } & \multicolumn{2}{|c|}{$(1)$} & \multicolumn{2}{|c|}{$(2)$} & \multicolumn{2}{|c|}{ (3) } \\
\hline & \multicolumn{2}{|c|}{ Full Sample } & \multicolumn{2}{|c|}{ General School } & \multicolumn{2}{|c|}{ Vocational School } \\
\hline & Coef. & SE & Coef. & SE & Coef. & SE. \\
\hline Predict YoS & $0.259 * * *$ & 0.070 & $0.302 * * *$ & 0.092 & $0.300 * * *$ & 0.109 \\
\hline Predict Yos\#SMK & 0.009 & 0.007 & & & & \\
\hline experience & $0.164 * * *$ & 0.043 & $0.153^{* * *}$ & 0.054 & $0.225^{* * *}$ & 0.086 \\
\hline experiencesqr & $-0.006 * * *$ & 0.002 & $-0.006 * *$ & 0.003 & $-0.009 * *$ & 0.004 \\
\hline lambda & $-0.886 * * *$ & 0.328 & -0.235 & 0.598 & $-1.356 * * *$ & 0.343 \\
\hline \multicolumn{7}{|l|}{ Control Mincer } \\
\hline cognitive & -0.001 & 0.002 & -0.002 & 0.002 & -0.003 & 0.003 \\
\hline male & $0.214^{*}$ & 0.113 & $0.423 * *$ & 0.200 & 0.092 & 0.126 \\
\hline married & $0.376 * * *$ & 0.104 & $0.325^{*}$ & 0.167 & $0.334 * *$ & 0.141 \\
\hline age & $-0.277^{* *}$ & 0.133 & -0.138 & 0.224 & $-0.446 * *$ & 0.201 \\
\hline agesqr & $0.005^{* *}$ & 0.002 & 0.002 & 0.003 & $0.007 * *$ & 0.003 \\
\hline rural & $-0.294 * * *$ & 0.074 & $-0.289 * * *$ & 0.102 & -0.193 & 0.119 \\
\hline formal & $0.676^{* * *}$ & 0.070 & $0.618^{* * *}$ & 0.091 & $0.737 * * *$ & 0.111 \\
\hline Constant & $13.675^{* * *}$ & 2.347 & $10.439 * *$ & 4.258 & $16.017^{* * *}$ & 2.905 \\
\hline Observations & 1,554 & & 969 & & 585 & \\
\hline Fstat & 38.23 & & 23.82 & & 31.81 & \\
\hline Prob > F & 0.000 & & 0.000 & & 0.000 & \\
\hline R-squared & 0.233 & & 0.191 & & 0.321 & \\
\hline Adj-Rsquared & 0.227 & & 0.182 & & 0.308 & \\
\hline
\end{tabular}


Moreover, columns 2 and 3 show the differences in educational outcomes for each type of secondary education (within-group). The return education for SMA graduates amounts to $30.2 \%$ ceteris paribus. This means that SMA graduates from high-quality schools supported by other educational inputs gain increases in future wages of $30.2 \%$ compared to SMA graduates from low-quality schools in other districts or cities. Similarly, in column 3, the return on education for SMK graduates is $30 \%$, ceteris paribus. Individuals from high-quality SMK who continue their education in college earn $30 \%$ higher wages than those who graduated from lower quality SMK.

Under the Presidential Regulation No. 8 of 2012 (2012) concerning the Indonesian National Qualifications Framework (Kerangka Kualifikasi Nasional Indonesia-KKNI), SMK graduates have the same level as SMA graduates, namely level 2 of 9 levels. Therefore, SMK graduates can continue their education up to 6 levels equal to graduating with a bachelor's degree, equivalent to the SMA path. Of course, those with a high KKNI level have better career development and can get higher wages than those who just graduated high school.

The results of the second step regression explain that school quality has an indirect effect on future income through the years of schooling and a direct influence on work participation. In line with Zimmermann (2021), the quality of SMK can directly affect the labor market because the curriculum provided at school may differ from the needs of the labor market. Meanwhile, school quality is indirectly manifested when vocational high schools provide more access to higher education pathways, such as vocational colleges, diplomas, expert competencies, or polytechnic education, which have more connections with the industrial and business sectors.

Moreover, Arum and Shavit (1995) explain that those who choose SMA tend to have higher ability and come from better family backgrounds than those who choose SMK, following the first regression result. Graduating from SMK might be a sign of lower capability; therefore, SMK graduates should continue their education to compete with general high school graduates. In addition to school quality in SMK, other educational inputs such as individual performance or family background also play an important role in continuing education.

\section{Conclusions}

This study observes the effect of general and vocational school quality on labor market outcomes. Using IFLS data, the estimation method follows a two-stage regression departing from the education production function of Hanushek (1979) and the income equation of Mincer (1974). We examine the labor market outcomes for general and vocational graduates, indirectly influenced by the educational input, one of which is school quality. This discussion of school quality might explain the differences in educational outcomes for both types of graduates because the years of schooling attended as a proxy for educational outcomes are affected by education inputs.

High school graduates attending high-quality schools, measured by the student-to-teacher ratio, better school facilities, and higher school expenditure per student, had significantly more years of schooling. However, the school quality reduced the years of schooling for vocational graduates compared to general graduates with the same school quality. Meanwhile, analyzing school quality within SMA or SMK shows different results. SMA graduates from better quality schools pursue more schooling than SMA graduates from relatively low-quality schools. Likewise, SMK graduates from high-quality schools pursue more years of schooling compared to individuals from low-quality SMK. Moreover, the school quality also affects the probability of working, and there is insufficient evidence that SMK quality increases the probability of work participation compared to the same SMA quality. Regardless of the quality of the school, all SMK in Indonesia is still facing limited access and match to the labor market. 
Furthermore, the difference in school quality between vocational and general schools is not a significant cause of the difference in return on education between SMA graduates and SMK graduates. However, within SMK, graduates from higher quality SMK earn higher future incomes than those from relatively low-quality SMK. The same also applies to SMA graduates according to differences in school quality. In other words, students from higher quality SMK or SMA increase years of schooling and indirectly have better labor market outcomes than students from less qualified SMA or SMK. Due to the importance of the quality of schools in determining labor market outcomes, the government can implement a policy to improve the quality of schools as stated in Indonesia's Voluntary National Review 2021, including the following: improved quality and competence of educators/instructors, especially with increasing vocational educator/ instructor training according to competence; revitalization and improvement of the quality of learning facilities and infrastructure work practice education; and enhancement involvement of instructors/ practitioners from industry to teach in academic units and vocational training.

Of course, the present study also has some limitations which must be kept in mind. This study limits its coverage by indirectly estimating the effect of schools' quality, both vocational and general high schools, on the return of the graduates' education in the labor market through years of schooling of the graduates. The result of this study is expected to contribute to the achievement of SDG 4, especially target 4.3 related to vocational and general secondary education. However, further public policy analysis has to be conducted to specifically analyze the indicators related to SDG 4 target 4.3 for vocational and general secondary schools.

This study applies the definition of school quality based on previous studies and the availability of longitudinal data from IFLS 2000, 2007, and 2014. The indicators do not necessarily reflect the broad definition of school quality; hence, further studies are encouraged to capture a broader definition of school quality. Moreover, this study only focuses on the effect of educational inputs on years of schooling, the quantity of education. We have not explained the effect on students' academic performance, which reflects the quality of education.

This study does not address the heterogeneity of individuals in terms of the types of majors at vocational school, majors at the college/diploma level, and compatibility with occupational skills. These issues might be addressed in future research once different data sets become available. These analyses will remain highly relevant in the future, given the continuing educational expansion and the rising importance of school quality, especially for vocational high schools.

There are some technical shortcomings of this study that need to be acknowledged. First, the IFLS community data on school characteristics are reported in seven-year intervals and aggregates schools into districts or cities. These issues generate some potential bias because they exaggerate the effect of school quality due to the unobserved school characteristics for each individual or school year (Hanushek et al., 1996). The two-step method we used can directly correlate educational inputs and Mincer's error terms. Several previous studies, such as Bedi and Edwards (2002) and Guo (2018), explained the direct influence of school quality on individual wages as a proxy for effective schooling.

\section{Acknowledgments}

The paper is based on the undergraduate thesis of the first author at the Faculty of Economics and Business Universitas Indonesia. We thank Chaikal Nuryakin, Ph.D., and Prani Sastiono, Ph.D., as examiners for the thesis. 


\section{Reference}

Arum, R., \& Shavit, Y. (1995). Secondary vocational education and the transition from school to work. Sociology of Education, 68(3), 187-204. https://doi.org/10.2307/2112684

Badan Perencanaan Pembangunan Nasional. (2021). Indonesia's Voluntary National Review 2021: Sustainable and resilient recovery from the covid-19 pandemic for the achievement of the 2030 agenda. http://sdgs.bappenas.go.id/laporan-voluntary-national-review-vnr-indonesia-2021

Bedi, A. S., \& Edwards, J. H. Y. (2002). The impact of school quality on earnings and educational returns evidence from a low-income country. Journal of Development Economics, 68(1), 157-185. https://doi.org/10.1016/S0304-3878(02)00010-X

Behrman, J. R., \& Birdsall, N. (1983). The quality of schooling: Quantity alone is misleading. The American Economic Review, 73(5), 928-946. https://www.jstor.org/stable/1814663

Bhismananda, P. G. (2020). The private rate of return to education investment between SMU and SMK according to ifls-5 data [Unpublished undergraduate thesis]. Universitas Indonesia.Card, D. (2001). Estimating the return to schooling: Progress on some persistent econometric problems. Econometrica, 69(5), 1127-1160.

Card, D., \& Krueger, A. B. (1992). Does school quality matter? Returns to education and the characteristics of public schools in the United States. The Journal of Political Economy, 100(1), 1-40. https://doi.org/10.1086/261805

Case, A., \& Yogo, M. (1999). Does school quality matter? Returns to education and the characteristics of schools in South Africa. SSRN. https://ssrn.com/abstract=227581

Central Statistic Agency . (2021a). Survei Angkatan Kerja Nasional: Tingkat pengangguran terbuka berdasarkan tingkat pendidikan [Data 2015-2020 set]. https://www.bps.go.id/indicator/6/1179/1/tingkat-pengangguran-terbuka-berdasarkan-tingkatpendidikan.html

Central Statistics Agency. (2021b). Survei Angkatan Kerja Nasional: Upah Rata - Rata Per Jam Pekerja Menurut Tingkat Pendidikan (Rupiah/Jam) 2015-2019 [Data set]. https://www.bps.go.id/indicator/19/1175/2/upah-rata---rata-per-jam-pekerja-menurut-tingkatpendidikan.html

Chen, D. (2009). Vocational schooling, labor market outcomes, and college entry. SSRN. https://ssrn.com/abstract=1327283

Dearden, L., Ferri, J., \& Meghir, C. (2002). The effect of school quality on educational attainment and wages. The Review of Economics and Statistics, 84(1), 1-20. https://doi.org/10.1162/003465302317331883

Duflo, E. (2001). Schooling and labor market consequences of school construction in Indonesia: Evidence from an unusual policy experiment. American Economic Review, 91(4), 795-813. https://doi.org/10.1257/aer.91.4.795

Garniss, D. (2006, October 3-5). Measuring quality of non-market output in education: Approaches developed in England [Paper presentation]. The Joint OECD/ONS/Government of Norway Workshop, London, United Kingdom.

Becker, G. . (1975). Investment in Human Capital: Effects on Earnings. NBER Chapters, National Bureau of Economic Research, Inc

Guo, D. (2018). Labour market impacts of school expenditure and class size: Evidence from China. The Journal of Development Studies, 54(7), 1137-1153. https://doi.org/10.1080/00220388.2017.1366451

Hanushek, E. A. (1979). Conceptual and empirical issues in the estimation of educational production functions. Journal of Human Resources, 14(3), 351-388. https://doi.org/10.2307/145575

Hanushek, E. A., Rivkin, S. G., \& Taylor, L. L. (1996). Aggregation and the estimated effects of school resources. The Review of Economics and Statistics, 78(4), 611-627.

Heckman, J. (1979). Sample selection bias as a specification error. Econometrica, 47(1), $153-161$. https://doi.org/10.2307/1912352

Jasmina, T. (2020). Vocational secondary education in indonesia: Yea or nay?. 政策科学, $27,3$.

Johnson, G. E., \& Stafford, F. P. (1973). Social returns to quantity and quality of schooling. The Journal of Human Resources, 8(2), 139-155. https://doi.org/10.2307/144731 
Mahirda, K., \& Wahyuni, K. (2016). Returning to general and vocational high-schools in Indonesia. Review of Economic and Business Studies, 9(2), 9-28.

Mincer, J. A. (1974). The human capital earnings function. In J. A. Mincer (Ed.), Schooling, Experience, and Earnings (pp. 83-96). National Bureau of Economic Research. https://doi.org.10.3386/w5548

Ministry of Education and Culture. (2020). Neraca Pendidikan. Retrived in https://npd.kemdikbud.go.id/

Ministry of Education and Culture. (2017). Konseptual Model Pengembangan Kompetensi Guru Produktif SMK Berbasis Industri. Direktorat Pembinaan Sekolah Menengah Kejuruan Direktorat Jenderal Pendidikan Dasar dan Menengah

Ministry of Education and Culture. (2016a). Program keahlian ganda, jawaban atas kekurangan guru produktif SMK. Jendela Pendidikan dan Kebudayaan, VII/November 2016, 6-22.

Ministry of Education and Culture. (2016b). Presidential instruction number 9 the year 2016 on revitalizing TVET schools (SMK) in the framework of improving the quality and competitiveness of Indonesian human resources. $\quad$ https://www.kemdikbud.go.id/main/blog/2016/09/presiden-jokowi-keluarkan-inprestentang-revitalisasi-smk

Ministry of Education and Culture of Indonesia and the United Nations Children's Fund. (2017). SDG4 baseline report for Indonesia. BAPPENAS and UNICEF.

Newhouse, D., \& Suryadarma, D. (2011). The value of vocational education: High school type and labor market outcomes in Indonesia. The World Bank Economic Review, 25(2), $296-322$. https://doi.org/10.1093/wber/lhr010

Organisation for Economic Co-operation and Development. (2020a). Indicator C1. How much is spent per student on educational institutions?.https://www.oecd-ilibrary.org/sites/5e4ecc25en/index.html?itemld=/content/component/5e4ecc25-en\#section-d1e20780

Organisation for Economic Co-peration and Development. (2020b). Total expenditure on educational institutions per full-time equivalent student, in vocational and general upper secondary education programmes (2017): In equivalent USD converted using PPPs. in Financial resources invested in education. OECD Publishing, Paris. https://doi.org/10.1787/16694582-en

Strauss, J., Witoelar, \& Sikoki, B. (2016). The fifth wave of the Indonesia family life survey (ifls5): overview and field

report. https://www.rand.org/content/dam/rand/pubs/working_papers/WR1100/WR1143z1/RAND_WR1143z 1.pdf

Strauss, J., Witoelar, F., Sikoki, B., \& Wattie, A. M. (2009). The fourth wave of the Indonesian family life survey (ifls4): overview and field report. https://www.rand.org/well-being/social-and-behavioralpolicy/data/FLS/IFLS/ifls4.html

Strauss, J., Beegle, K., Sikoki, B., Dwiyanto, A., Herawati, Y., \& Witoelar, F. The third wave of the Indonesia family life survey (ifls): overview and field report. https://www.rand.org/well-being/social-andbehavioral-policy/data/FLS/IFLS/ifls3.html

Strayer, W. (2002). The returns to school quality: College choice and earnings. Journal of Labor Economics, 20(3), 475-503. https://doi.org/10.1086/339674

Presidential Regulation No. 18 of 2020 concerning the National Medium-Term Development Plan of 20202024 (RPJMN 2020-2024). (2020). https://jdih.bappenas.go.id/peraturan/detailperaturan/1037

Presidential Regulation No. 8 of 2012 concerning the Indonesian National Qualifications Framework (Kerangka Kualifikasi Nasional Indonesia-KKNI). https://peraturan.bpk.go.id/Home/Download/68829/Peraturan\%20Presiden\%20No\%208\%20Tahun\%2 02012.pdf

Quarina, Q., \& Pasay, N. H. A. (2007). Rates of returns to vocational and general upper secondary education and experience in addressing the hollow middle in Indonesia. Economics and Finance in Indonesia, 58(3), 239- 267.

Zimmermann, M. (2021). Postsecondary and labour market outcomes of vocational vs. general higher track secondary pupils. Education 290nomics, 213-231, https://doi.org/10.1080/09645292.2021.1871884 